\title{
新潟大学工学部福祉人間工学科 関根・大河研究室
}

研究室紹介

Sekine and Ohkawa Lab., Dep. of Biocybernetics, Faculty of Engineering, Niigata University

専門会員 関 根 征 士

新潟大学工学部福祉人間工学科教授

新潟大学は, 医歯系学部が新潟市の中心街に近い旭 町・西大畑地区キャンパスにあり, 工学部などの 7 学部 と大学本部が新潟市郊外の五十嵐地区キャンパスにあ る。五十嵐地区キャンパスからは佐渡が一望できる.

福祉人間工学科は, 情報工学科と電気電子工学科を母 体学科として1998年に設置され, 福祉機器工学と福祉生 体工学の 2 大講座からなる. 著者の関根と大河正志助教 授はともに電気電子工学科から福祉生体工学講座に移籍 して現在に至る（図1).

新潟大学大学院自然科学研究科は理学, 工学, 農学の 3 学部と積雪地域災害研究センターを基盤として構成さ れた独立の教育研究機関で，5年制の区分制大学院であ る. 現代の多様化した学問的, 社会的要請に柔軟に応之 るため, 自然科学の全分野に対し, 従来の学問分野にと らわれず，弾力性のあるように，博士前期 2 年課程には 5 系列（物質, 生産, 生命, 環境, 情報） 9 専攻, 博士後 期 3 年課程には 3 系列（物質・生産, 生命・環境, 情報） 5 専攻が設置されている. 現在, 従来の特徴を活かしつ つより柔軟に社会の要請に対応するための改革が推進さ れているが，「人間支援科学分野」の充実を期している.

関根研究室と大河研究室は「光の人間支援工学」が共 通のキーワードであり協力して教育研究を遂行している

(図 2 ).

関根研究室は, 照明光源分野である(1)マイクロキャビ ティ白熱光源に関する研究と(2)タングステンクラスター 光源に関する研究, 光情報処理分野である(3)液晶ディス プレイ導光システムの高効率化に関する研究(4)光機能材 料を用いた実時間ホログラムに関する研究, 及び視覚光 学分野である(5)二ューラルネットワークによる色弁別と 色覚機構に関する研究と (6)快適光空間の快適性評価に関 する研究などを推進している.

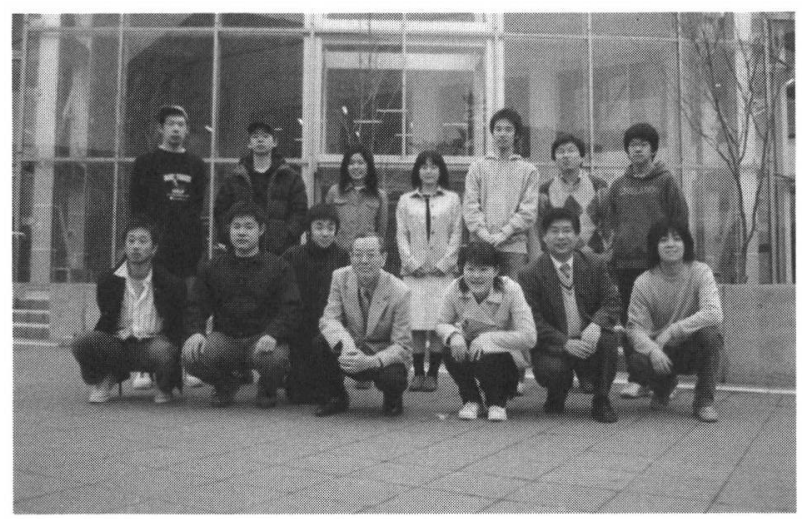

図 1 関根・大河研究室の教職員と大学院生

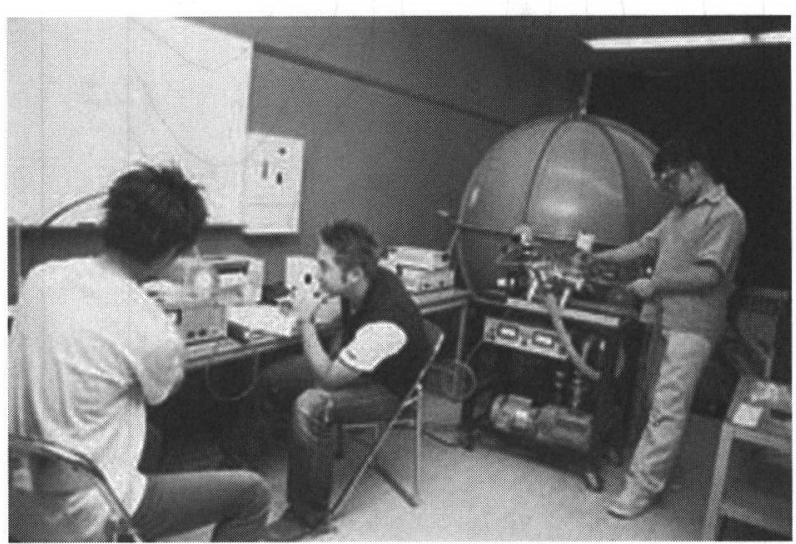

図 2 クラスター光源の発光実験

蛍光ランプの光は頭上に輝く太陽の光であり,「働きの 光」である. 一方, 白熱電球の光は灯火の光であり,「安 らぎの光」である. 研究テーマ(1)と(2)の光源は蛍光ラン プを凌ぐ省工ネ白熱光源として期待される。これら光源 の発光特性は発光材料の複素屈折率によって決定される ため, 白熱状態に熱也られた発光材料の複素屈折率の工 リプソメトリーによる測定も推進している。

大河研究室は, 主に「光集積回路センサ, 音声コミュ ニケーション支援機器, 光情報処理の研究」を行ってい る. 光集積回路センサは光波利用センシングと光集積回 路技術を融合したセンサで，小型·軽量，光軸調整不要， 無誘導性, 防爆性などの利点を有する。電磁誘導の影響 を受けず，漏電の心配もないため，医用計測分野への応 用に適しており，カテーテルに組み込み可能な小型・高 感度光集積回路圧力七ンサの開発を行っている. センサ は, 感圧部となる薄板状のダイヤフラムとその上を通る 光導波路からなる. センサ作製におけるダイヤフラムと 光導波路との位置合わせ精度が十分でないため, ダイヤ フラムサイズは $1.5 \mathrm{~mm} \times 7.5 \mathrm{~mm} \times 23 \mu \mathrm{m}$ とまだ大きい が, 0〜3000Pa の血圧をセンシングすることができる.

さらに, 光とは関係ないが, 音声コミュニケーション 支援機器に関する研究も行っている. 言語障害者のコ ミュニケーションを支援する機器として VOCA (Voice Output Communication Aids) があるが，その音声は 画一的で，ときには人間味のない音声に不快感を感じる こともある.この研究では, 音声の個人性を抽出し, 機 器使用者 (言語障害者) の声質で音声を発する VOCAの 開発を目指している。機器使用者の声質の抽出にはスペ クトル分析法の 1 つであるケプストラム分析を用い, 音 声合成には健常者の音声を基にした話者変換技術を利用 することを考え，研究を進めている. 


\title{
東北文化学園大学 谷口研究室・家名田研究室
}

研究室紹介

Taniguchi Lab. and Yanada Lab. of Tohoku Bunka Gakuen Univiversity

\author{
専門会員 谷口正成 正会員 家名田 敏 昭 \\ 東北文化学園大学大学院健康社会システム研究科教授東北文化学園大学科学技術学部助教授
}

\section{1.はじめに}

東北文化学園大学は平成 11 年 4 月, 仙台市内の JR 仙 山線「国見駅」前に医療福祉学部，総合政策学部，なら びに，科学技術学部の三学部で開学された。 とくに，科 学技術学部には, 高度な情報処理技術者の育成と, 教育· 研究を目的として応用情報工学科が開設された。また， 本年 4 月, 大学院健康社会システム研究科が開設された。

平成12年 4 月, 谷口は名城大学から, 家名田は東北大 学加着任し, 同時に,「谷口研究室」と「家名田研究室」 を開室した。ここで，両研究室の概要を紹介する。

\section{2. 谷口研究室 (図 1)}

谷口研究室は前任地の名城大学と同様,「光応用パ夕一 ン計測」を研究テーマとして，ホログラフィック変位パ ターンの $3-\mathrm{D}$ 計測システムの全自動化とその応用, 光 ファイバのスペックルノイズとそのセンサへの応用，な らびに, 機構デバイスの接触信頼性に関する研究を継続 した。また，新たに，赤外放射計測とその情報処理，な らびに, 診断評価への応用, さらに, 交通流の画像計測 システムの開発と交通信号の最適制御に関する研究など に着手した。

とくに, 東北学院大学工学部の中鉢研究室との共同研 究により，熱ストレスを受けた骨の膨張，変形計測にホ ログラフィ干渉計測システムとサーモグラフィ計測シス テムを応用し，従来解析が困難であった生体の熱ストレ スの影響を明らかにした。また，地元企業との共同研究 により, ペーパ八ニカムパネルの浸水検出, ならびに, 喫煙，飲酒時の生体への影響について，サーモグラフィ 計測システムの応用を試み，その有効性を実証した。

これらの研究成果の一部をIEEE/IMTC (Instru-

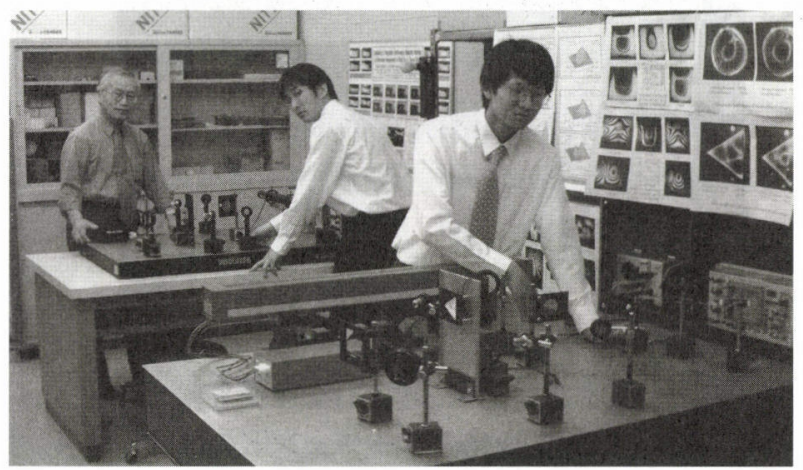

図 1 谷口研究室 (光応用パターン計測システム) mentation and Measurement Technology Conference), ならびに, 照明学会全国大会, 同学会赤外放射の 情報処理，生体への応用技術に関する研究調查委員会な どに報告した。

\section{3。家名田研究室（図2)}

家名田研究室では, 東北大学在任中より研究を続けて きた悪性腫瘍などに対する治療方法の一つである温熱療 法 (ハイパーサーミア) の高機能化と実用化に関する研 究, ならびに, RF 加温やソフトヒーティング法などの温 熱療法用の高機能かつ融通性の高い高周波電源の開発に 関する研究を行っている。

さらに, 本学着任後, 情報処理に不可欠なコンピュー タシミュレーション解析システムを構築した。 本システ ムは 2 台のサーバコンピュータと 20 台のクライアント コンピュータ, さらに，2台のレーザカラープリンタ， 1台のスキャナで構成されている。また，シミュレータ には, MATLAB / Simulink, Orcad / PSpice, ANSYS / Multiphysics, MSC Marc $\cdot$ Marc Mentat などを導入した。

現在, 本システムを用いて, 生体内温度分布解析を行っ ている. また, 電気機器の熱解析, 動作解析を行い, こ れらの結果をもとに, 電気機器の特性改善, 性能向上に 関する研究を進めている.

\section{4.おわりに}

本年，本学は完成年度を迎え，さらに，大学院が開設 された。 大学院には, 健康福祉専攻と生活環境情報専攻 が設けられ，両研究室では，今後，生体，医療，環境， 情報, 計測をキーワードとした研究を進める方針である。

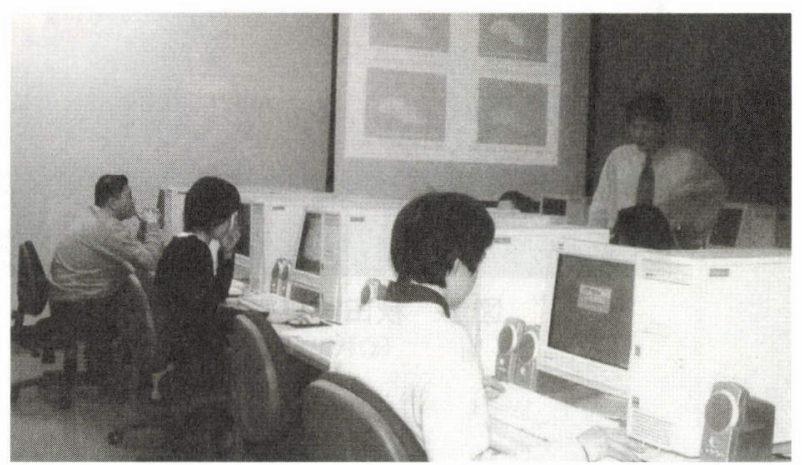

図 2 家名田研究室 (計算機シミュレーション解析システム) 